\author{
Review article
}

\title{
PERMANENT GNSS OBSERVATIONS AT AGH-UST SATELLITE OBSERVATORY
}

\author{
Jacek Kudrys \\ Faculty of Mining Surveying and Environmental Engineering, \\ AGH University of Science and Technology, Kraków, Poland
}

\begin{abstract}
GPS satellite observations at the Faculty of Mining Surveying and Environmental Engineering AGH-UST are conducted since the early 90 s of the last century. In 2001, efforts have been made on getting permanently functioning GPS station. At present, observatory is EPN operational center for two GNSS stations KRAW and KRA1. Moreover, KRA1 station is one of fundamental control points in polish horizontal network. The article gives the history and scope of the research carried out in the satellite observatory AGH-UST during the period 2001 - 2015.
\end{abstract}

Keywords: satellite observatory, GNSS, AGH-UST

\section{Introduction}

AGH-UST satellite observatory is located in the building of Faculty of Mining Surveying and Environmental Engineering at AGH University of Science and Technology in Kraków. Currently (April 2016), the observatory is equipped with two GNSS receivers, which continuously collect observational data. The observatory is also equipped with automatic meteorological station and rubidium external frequency standard. GNSS antennas and the meteorological station are installed in the northern part of the roof of the C-4 building (fig. 1). Both antennas are placed on specially prepared concrete pillars with dimensions of $70 \times 70 \times 160 \mathrm{~cm}$, which were part of geodetic calibration base. Antennas are mounted on basis of forced centering.

\section{History of the AGH-UST satellite observatory}

GPS satellite observations at the Faculty of Mining Surveying and Environmental Engineering AGH-UST are conducted since the early 90 s of the last century. In that time, with the intensification of studies using satellite navigation system, it became necessary to have a permanent GPS station with precisely determined coordinates. First determination of coordinates of a point designated to permanent observation was made between March and April 2001. Coordinates were determined in ITRF with reference to the permanent IGS stations JOZE, WTZR and PENC (Kudrys, 2002). This first measurements were made with typical field receiver - Ashtech Z-Surveyor with ASH701008.01B antenna. 


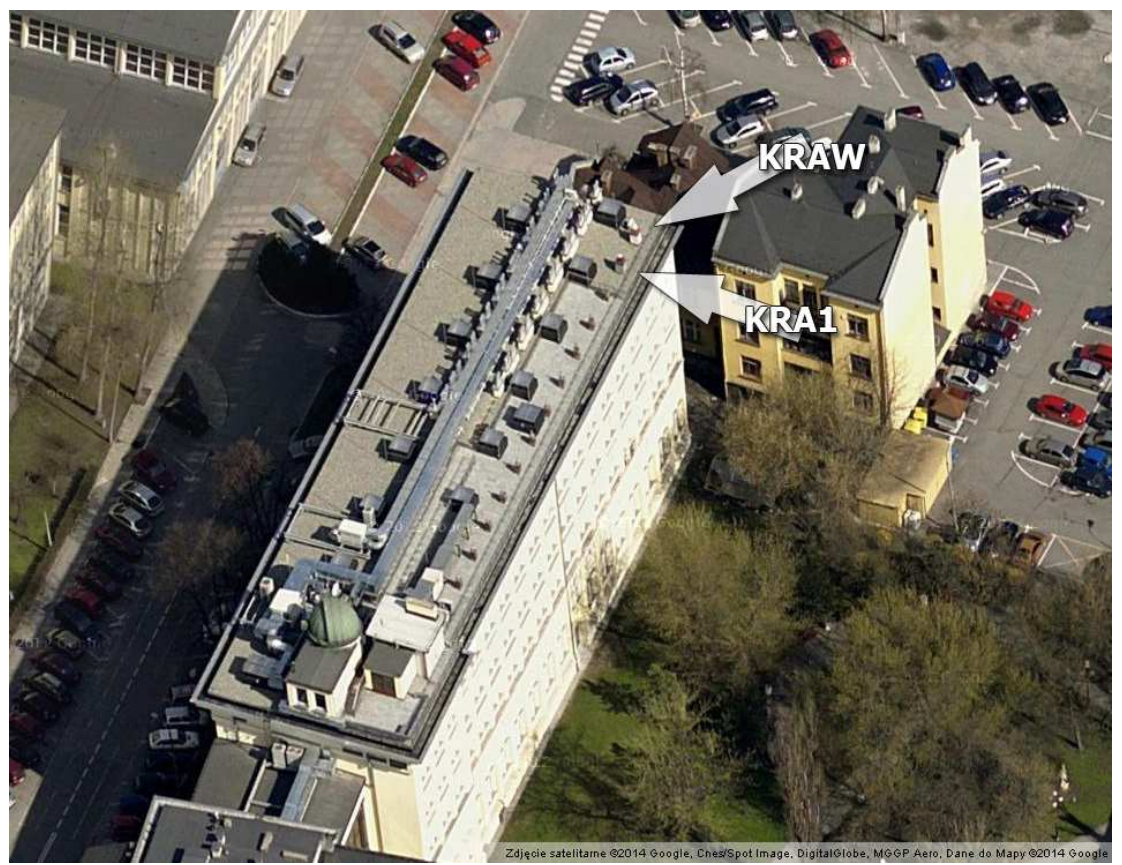

Fig. 1. KRAW and KRA1 stations located on the roof of C-4 building at AGH-UST (maps.google.pl)

Receiver intended for permanent observations was installed in December 2002. In order to start continuous work, a pillar which was part of geodetic calibration base has been prepared. Also lightning protection system was modernized to protect GPS antenna and meteorological station. Installed at this time Ashtech MicroZ (UZ-12) receiver with ASH701945C_M antenna - working so far - allows only for GPS observations. It simultaneously tracks up to 12 satellites and collect dual frequency code and phase data. From 26 January 2003 the receiver as a permanent station KRAW has been included into EPN (EUREF Permanent Network) tracking network (EUREF mail, 2003a, EUREF mail, 2003b). Since then, the data from AGH-UST observatory are collected and provided without interruption to the EPN data centers.

At the beginning of 2003, in the provinces of Silesia, pilot project of active geodetic network ASG-PL was launched. Access to the observations made at ASG-PL permanent stations along with observations from KRAW station, created the opportunity to conduct research related to modeling of the atmosphere in order to improve ellipsoidal height determination from GPS measurements (Góral, 2003b, Góral, 2003a). Localization of the permanent stations also allowed for geodynamic research in the area of Upper Silesian Industrial Region (GOP) (Banasik et al., 2003, Góral et al., 2005, Banasik and Góral, 2005). At that time, AGH-UST observatory begins to participate in the EUREF-IP project, and starts to provide data from the KRAW station in real-time (EUREF mail, 2003c). From February 2005, the observatory is running NtripCaster software, which is part of the Ntrip protocol (Kudrys, 2005), and data from KRAW station are accessible from own server.

Since October 2006, observations from KRAW station are available in the Malopolska Precise Positioning System (MSPP) - local permanent stations network. MSPP consist of stations located in Malopolska and Silesia regions and includes former ASG-PL network. MSPP functionality is utilized in positioning for economic purposes and among others, by Tatra Voluntary Rescue Service (TOPR) team monitoring system and supports emergency medical team management system (Antosiewicz, 2007). 
Fig. 2. Cycle slips for KRAW station in year 2008 (epncb.oma.be)

In 2008 KRAW station has been included in ASG-EUPOS - active geodetic network for precise positioning and navigation in Poland. In the same year, the GPS receiver has been connected to external rubidium frequency standard. It improved the quality of the received satellite data and resulted in a clear reduction of number of cycle slips in the phase observations (fig. 2).

Since 2010, in the observatory, second receiver intended for permanent observations is installed. The receiver - Trimble NetR5 with TRM57971.00 antenna - is capable of receiving GPS and GLONASS signals. This new receiver, as the KRA1 permanent station, was included into the EPN tracking network in March 2010 (EUREF mail, 2010). Since that time, the observatory has two simultaneously working receivers from which the data are avaliable in the EPN. With the launch of the station KRA1, it replaces the existing station KRAW in ASG-EUPOS and MSPP networks.

\section{Research carried out in the AGH-UST satellite observatory}

Since the beginning of the activities of the observatory, works on monitoring of stability of the permanent stations are carried out. As a result of the research based on vector solution between nearest permanent stations, amplitude of the seasonal changes of KRAW station coordinates has been determined. Periodical changes are visible mainly in the northern component (Góral and Kudrys, 2006, Góral and Jasiurkowski, 2006). The calculated values were confirmed by studies of results of EPN combined solutions (fig. 3).

Using the observations made at the KRAW station, along with data from neighboring permanent stations (ASG-PL), research related to ionospheric and tropospheric refraction models were conducted (Skorupa, 2006). Further study concentrates on impact of GPS antenna phase center offset on vector solution (Góral \& Kudrys, 2007), as well as methods of integer phase ambiguities determination (Skorupa, 2007, Skorupa, 2011).

In 2007, for the KRAW station several gravity field parameters were specified: absolute gravity value, gravity vertical gradient, Bouguer and Faye anomaly and vertical deflection components. Also normal height and height anomaly were calculated (Banasik, 2007). In 
Fig. 3. KRAW station coordinates north component (epncb.oma.be).

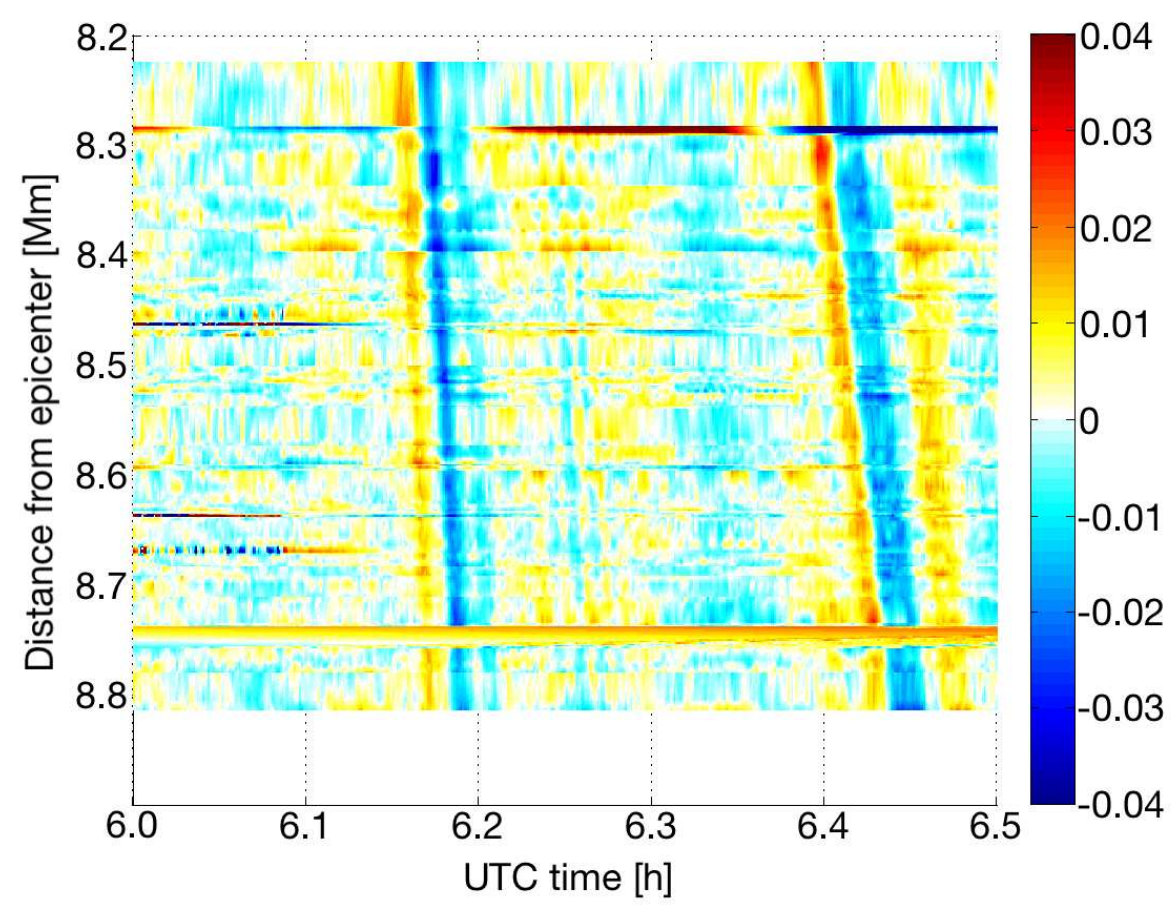

Fig. 4. Radial component of seismic waves $S$ and LR caused by Honshu 2011 earthquake observed at ASG-EUPOS stations. Color scale in meters.

2010, gravity absolute value was measured once more (Banasik et al., 2010). As a result, the observatory gained features of an integrated multi-dimensional geodetic control.

GNSS observations performed in the observatory were the basis for industrial works, e.g. verifying conversion of coordinates from the Krakow local frame to the national PL2000 frame or monitoring the stability of leveling network reference points (Banasik \& Kudrys, 2007).

Since 2007, in the framework of integration of satellite observations and classic measurements, research on automatic determination of vertical deflection components from astrometric and GNSS observations were carried out. Result of this work was the construction of a measuring device and development of specialized software to determine the components of vertical deflection (Kudrys, 2007, Kudrys, 2009a, Banasik et al., 2010).

In 2008, polish active geodetic network ASG-EUPOS for precise positioning and navigation has been started. It created a number of new research opportunities. As part of the research conducted at the AGH-UST observatory a method of monitoring the impact 


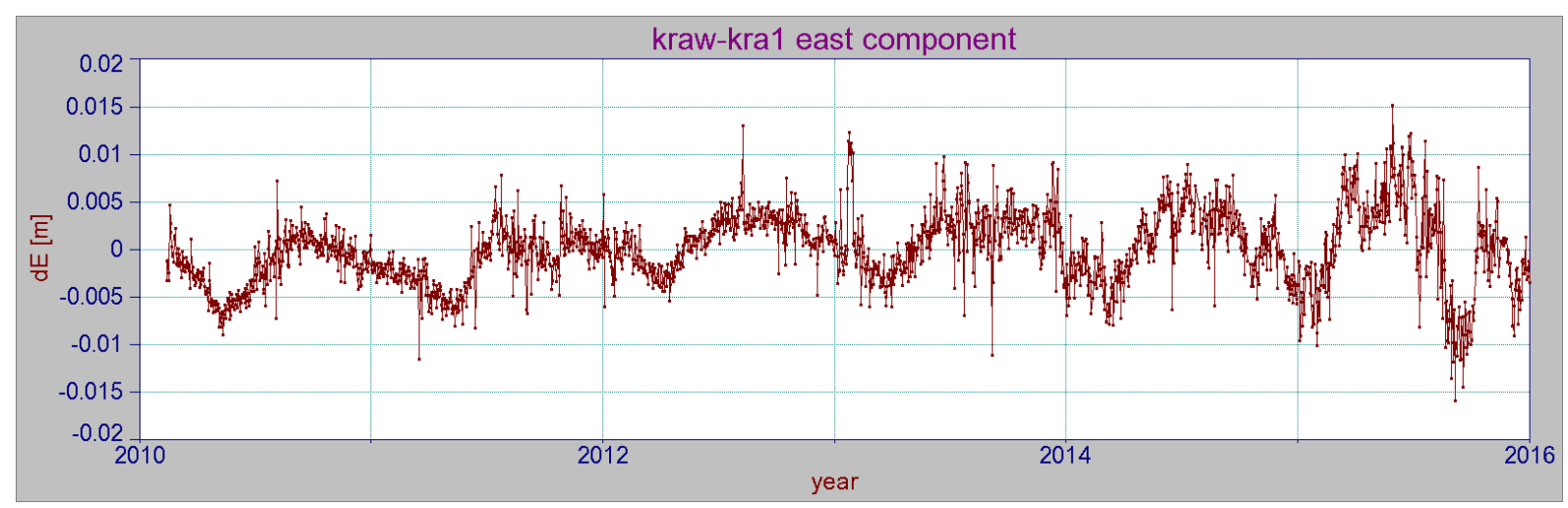

Fig. 5. Difference of east component of KRAW and KRA1 stations from PPP solution

of distant earthquakes were developed. The method uses observations registered on the permanent stations network (Kudrys, 2009b). Using the results of PPP (Precise Point Positioning) processing of observations made at the ASG-EUPOS stations, image of seismic wave propagation was obtained. This method, for example, helped to identify $S$ waves (body wave) and LQ (Love wave) caused by the earthquake in the area of Honshu in 2011 (fig. 4).

Currently, within the framework of research conducted in AGH-UST Observatory, time series of coordinates gained from various GNSS measurement techniques are analyzed (Kudrys and Krzyżek, 2011, Maciuk, 2012, Krzyżek and Skorupa, 2012, Maciuk, 2016). Moreover, the observatory operates calculation service to determine position of KRAW and KRA1 stations with PPP technique. Calculations are performed in daily basis. In this way changes of coordinates of these points are monitored (Fig. 5). At the observatory studies associated with combined use of GPS and GLONASS signals for precise point positioning are also carried out (Maciuk, 2015).

Recently, studies related to the GNSS satellite orbit determination based on generalized problem of two centers have been undertaken. (Góral and Skorupa, 2012, Góral and Skorupa, 2015, Skorupa and Góral, 2015). These studies create an opportunity to develop a uniform method for determining orbital parameters for various satellite systems.

\section{Acknowledgement}

This work has been supported by the project No. 11.11.150.006 at the Department of Geomatics, AGH University of Science and Technology, Kraków, Poland.

\section{References}

Antosiewicz, M. (2007). System pozycjonowania precyzyjnego o przeznaczeniu ogólnopolskim dla województwa małopolskiego. Geomatics and Environmental Engineering, 1/1(1), 23-42.

Banasik, P. (2007). Wyznaczenie wysokości normalnej oraz charakterystyk pola ciężkościowego dla stacji permanentnej KRAW. Geomatics and Environmental Engineering, 1/1(1), 53-60.

Banasik, P. \& Góral, W. (2005). Eastern Silesian Geodynamic GPS Network - Preliminary results of the campaign 2003-2004. Acta Geodynamica et Geomaterialia, 2(3 (139)), $1-6$.

Banasik, P., Góral, W., Maciaszek, J., \& Szewczyk, J. (2003). Wykorzystanie aktywnej sieci geodezyjnej (ASG-PL) do monitorowania przemieszczeń punktów na obszarze GOP. Geodezja, 9(2/1). 
Banasik, P. \& Kudrys, J. (2007). Weryfikacja wyników przeliczenia współrzędnych z układu lokalnego miasta Krakowa (ULK) do układu "2000" z wykorzystaniem stacji permanentnej GPS "KRAW". Geomatics and Environmental Engineering, 1/2, 13-21.

Banasik, P., Kudrys, J., Rogowski, J. B., \& Skorupa, B. (2010). Automatyzacja procesu wyznaczania składowych odchylenia linii pionu z obserwacji zenitalnych gwiazd $i$ sygnałów GPS. Kraków: Wydawnictwa AGH.

EUREF mail. (2003a). EUREF mail no. 1550. http://epncb.oma.be.

EUREF mail. (2003b). EUREF mail no. 1554. http://epncb.oma.be.

EUREF mail. (2003c). EUREF mail no. 1561. http://epncb.oma.be.

EUREF mail. (2010). EUREF mail no. 4980. http://epncb.oma.be.

Góral, W. (2003a). Precyzyjny pomiar wysokości elipsoidalnej za pomocą GPS na obszarze ograniczonym siecią stacji permanentnych KRAW+ASG-PL. Geodezja, 9(2/1), 217223.

Góral, W. (2003b). The concept of utilizing the Silesian Active Geodetic Network for determination of current parameters of local differential troposheric refraction. ACTA MONTANA, Series A(24 (131)), 105-108.

Góral, W., Banasik, P., Maciaszek, J., \& Szewczyk, J. (2005). Badawcza sieć geodynamiczna na obszarze wschodniej części Górnośląskiego Zagłębia Węglowego. Kraków: UWND $\mathrm{AGH}$.

Góral, W. \& Jasiurkowski, D. (2006). Preliminary results of the analysis of the GPS vector solutions time series (VSTSGPS) in ASG-PL Permanent Network. Acta Geodynamica et Geomaterialia, 3(3 (143)), 23-29.

Góral, W. \& Kudrys, J. (2006). Analysis of stability of permanent GPS stations KRAW, KATO and ZYWI. Acta Geodynamica et Geomaterialia, 3(3 (143)), 19-22.

Góral, W. \& Kudrys, J. (2007). Oblicznie poprawek uwzględniających wpływ charakterystyk anten w pomiarach fazowych GPS. Geomatics and Environmental Engineering, 1/1(1), 133-139.

Góral, W. \& Skorupa, B. (2012). Determination of intermediate orbit and position of GLONASS satellites based on the generalized problem of two fixed centers. Acta Geodynamica et Geomaterialia, 9(3 spec. iss.), 283-290.

Góral, W. \& Skorupa, B. (2015). Calculation of position and velocity of GLONASS satellite based on analytical theory of motion. Artificial Satellites, 50(3), 105-114.

Krzyżek, R. \& Skorupa, B. (2012). Analysis of Accuracy of Determination of Eccentric Point Coordinates of the KRAW Permanent Geodetic Station in RTK GPS Measuring Mode with the Application of the NAWGEO Service of the ASG-EUPOS System. Geomatics and Environmental Engineering, 6(4), 35-46.

Kudrys, J. (2002). Wstępne wyznaczenie współrzędnych punktu KRAK w nawiązaniu do stacji permanentnych IGS z wykorzystaniem oprogramowania Bernese 4.2. Geodezja, $8(1)$.

Kudrys, J. (2005). Transmisja poprawek do obserwacji w trybie RTK GPS z wykorzystaniem protokołu Ntrip. Geodezja, 11(2), 301-308.

Kudrys, J. (2007). Automatic Determination of Vertical Deflection Components from GPS and Zenithal Star Observations. Acta Geodynamica et Geomaterialia, 4(4 (148)), 169-172.

Kudrys, J. (2009a). Automatic determination of the deflections of the vertical - first scientific results. Acta Geodynamica et Geomaterialia, 6(3 (155)), 233-238.

Kudrys, J. (2009b). Time-frequency analysis of the Sumatra 2004 earthquake impact on GPS stations. Report on the symposium of the IAG sub-commission 1.3a Europe, 42 EUREF Publications(17). 
Kudrys, J. \& Krzyżek, R. (2011). Analysis of Coordinates Time Series Obtained Using the NAWGEO Service of the ASG-EUPOS System. Geomatics and Environmental Engineering, 5(4), 39-46.

Maciuk, K. (2012). An Analysis of Coordinate Changes of the Permanent Geodetic Stations KRAW and KRA1 During the Flood in 2010. Geomatics and Environmental Engineering, 6(1), 51-57.

Maciuk, K. (2015). Integration of GPS and GLONASS systems in geodetic satellite measurements. Geoinformatica Polonica, 14, 75-83.

Maciuk, K. (2016). The study of seasonal changes of permanent stations coordinates based on weekly EPN solutions. Artificial Satellites, 51(1), 1-18.

Skorupa, B. (2006). Praktyczna realizacja algorytmu estymacji lokalnej różnicowej refrakcji jonosferycznej i troposferycznej na obszarze ograniczonym siecią stacji permanentnych ASG-PL. Geodezja, 12(1), 95-104.

Skorupa, B. (2007). Wyznaczenie drugoróżnicowych całkowitoliczbowych nieoznaczoności cykli w pomiarach fazowych GPS zarejestrowanych na punktach lokalnej sieci stacji permanentnych. Geomatics and Environmental Engineering, 1/1(1), 213-221.

Skorupa, B. (2011). Study on GPS Phase Ambiguity Resolution Effectiveness with use of LAMBDA De-Correlation Method. Geomatics and Environmental Engineering, 5(2), 81-87.

Skorupa, B. \& Góral, W. (2015). Położenie i prędkość satelitów GNSS na postawie uogólnionego zagadnienia dwóch stałych centrów grawitacji. Kraków: Wydawnictwa AGH.

\footnotetext{
Authors: Jacek Kudrys jkudrys@agh.edu.pl

Department of Geomatics

Faculty of Mining Surveying and Environmental Engineering,

AGH University of Science and Technology, Kraków, Poland

30 Mickiewicza Av., 30-059 Kraków, Poland
} 